\title{
Legal System Reform and Challenges on Assurance of Human Rights Standards in Vietnam
}

\author{
Nguyen Thi Hong Yen \\ Researcher, Lecturer Hanoi Law University (HLU), VIETNAM \\ Email: Hongyengnguyen.hlu@gmail.com; nguyenhongyen@hlu.edu.vn
}

\begin{abstract}
Since the Doi Moi (Vietnam's economic reform) in 1986 to date, Vietnam has continuously made efforts to reform its legal system to better adapt with requirements to develop in different historical periods. Vietnam considers ensuring fundamental human rights as one of the cross-cutting goals in national development policies and strategies. It is undeniable that the outcomes of legal system reform had a positive impact on all aspects of life and on the assurance of human rights and citizen's rights in particular. However, due to the effects of e international integration and 4.0 industrial revolution the emergence of new-generation trade agreements (FTAs), the current legal system in Vietnam has revealed certain limitations that need to be improved in order to better guarantee fundamental rights. With the objective to bring about the general picture of legal reform on human rights in the recent years in Vietnam, this article will focus on introducing the legal system and its impact on the assurance of human rights standards and highlighting the priorities that need to be revised.
\end{abstract}

Keywords: Vietnamese Legal System, Legal Reform, Human Rights.

\section{INTRODUCTION}

Legal reform is one of the most important duties of a nation to ensure their legal systems are effective and comprehensive. The reform also guarantees the harmony between national laws and international treaties. Since the declaration of independence in 1945, along with the process of national construction and development, especially after ratification of international treaties in general and human rights treaties in particular, Vietnam has continuously made efforts to improve the system of policies and laws. Particularly for human rights issues, Vietnam has paid special attention to and always considered the assurance of fundamental human rights as one of the cross-cutting goals in national development policies and strategies. Article 14 in Vietnam Constitution in 2013 stipulates:

"In the Socialist Republic of Vietnam, political, civic, economic, cultural and social human rights and citizen's rights are recognized, respected, protected and guaranteed in concordance with the Constitution and the law", and

"the State guarantees and promotes the people's mastery; acknowledges, respects, and protects human rights and citizens' rights" (Article 3). 
In 2005, Vietnam enacted two important strategies namely the Resolution 48NQ/TW on Legal System Development Strategy to 2010 with a Visions to 2020 (LSDS), and Resolution 49-NQ/TW on Judicial Reform Strategy for the period until 2020 (JRS) which defines the strategic objective of building the transparent, strong, democratic and strict judiciary to protect justice and serve the people and the Socialist Republic of Vietnam. Both are designed to bring the country closer to developing as a 'socialist rule of law' state.

After 15 years of implementing the reforms, the legal system of Vietnam has constantly been strengthened and improved and is now sufficient to adjust socioeconomic relations. This creates a legal basis for state management as well as the legal environment and frameworks to guide and promote socio-economic development. In terms of human and citizen's rights issues, Vietnam has made remarkable progress. Civil, political, economic, cultural and social rights have been recognized sufficiently in the legal system. The rights of vulnerable groups including women, children, elderly, people with disability have also been stipulated and guaranteed. The mechanism to protect human rights such as legislative, law enforcement, judicial agencies have been reformed in organizational and functional structure to better perform their duties, functions in assuring human rights are recognized in laws. Nevertheless, due to the impact of international integration and 4.0 industrial revolution, the current legal system has shown limitations that need to be renovated such as lack of comprehensiveness and stability, containing conflicts and overlaps and low level of feasibility which has not reached the level of a legal system for creation and development. ${ }^{1}$

In 2020, Vietnam will conduct a review of 15 years of implementing the Resolution no.48-NQ/TW and Resolution no.49-NQ/TW, therefore, it is critical to do review research on the impact of the legal system reform. This can be considered as evidence for the orientations to improve provisions of laws. The following analysis will primarily focus on (i) studying the process of improving laws on human rights (ii) the implication of legal reform on ensuring human rights in Vietnam in the recent years, thereby (iii) highlighting content that needs to be prioritized for improvements in upcoming years.

\section{VIETNAMESE LEGAL SYSTEM AND THE NEED FOR REFORM IN THE CONTEXT OF INTERNATIONAL INTEGRATION}

In Vietnam, the National Assembly (hereinafter referred to as the NA) is the highest representative organ of the people, the highest organ of state power of the Socialist Republic of Viet Nam, the sole organ that has the constitutional and legislative rights. In addition to its legislative authority, the NA has decision-making authority in

1 Dinh Dung Sy, "Hệ thống pháp luật Việt Nam trong tiến trình đổi mới và phát triển đất nước" (2020) 401:1 Legal Research Journal, online: <http://www.lapphap.vn/Pages/TinTuc/210462/ He-thong-phap-luat-Viet-Nam-trong-tien-trinh-doi-moi-va-phat-trien-dat-nuoc.html>.

2 Vietnam Government Portal, "Introduction about Political system of Vietnam”, (2019), online: <http://chinhphu.vn/portal/page/portal/English/TheSocialistRepublicOfVietnam/AboutVietna $\mathrm{m} /$ AboutVietnamDetail? categoryId=10000103\&articleId=10001578>. 
numerous crucial areas in relation to national socio-economic development including state budgets, financial and monetary policies, taxation and other significant policies on domestic and foreign policy; ${ }^{3}$ sets out the regulations on the operation and activities of the executive, procuracy and judiciary. The NA exercises supreme oversight on the observance of the Constitution, laws and resolutions of the NA and all activities of the State's actors (Article 70). ${ }^{4}$ In addition to the Constitution and laws enacted by the NA, there are numerous regulations issued by other State authorities. However, according to Phan Lan Huong, ${ }^{5}$ there is no clear distinction between legal norms issued by the NA from those issued by the executive. In practice, competent authorities or persons tend to follow the legal normative documents issued by executive organs rather than those issued by NA because they consider that those issued by the Government detail and guide the implementation of the legislation issued by the NA. This practice has led to different opinions regarding the hierarchy of Vietnamese legislation.

The reform process in Vietnam in the late 1980s generated significant gains in economic growth and integration with international markets was accompanied with transformation in the central state that involved devolution processes and changes in the state's internal make-up, re-examination of functions and roles. The country recognized the establishment and improvement of the legal system essential to meet its socio-economic development objectives. Accordingly, the legal system should be improved extensively i.e. covering all social and economic fields and intensively, i.e. enhancing quality of drafting legal acts and revise these acts to make them able to better regulate social relations. ${ }^{6}$

Since the amendment of 1992 Constitution, Vietnam has made substantial progress in creating a national legal framework and strengthening institutional capacity for legal and judicial reform. In 2005, the CPV enacted two important strategies $^{7}$ setting out the trajectory for the legal system and judiciary reform, both of which are designed to bring the country closer to building a 'socialist rule of law' state. Under the Resolution 48-NQ/TW on Legal System Development Strategy to 2010 with a Visions to 2020 (LSDS), and Resolution 49-NQ/TW on Judicial Reform Strategy for the period until 2020 (JRS), the legal normative system is being reinforced, state governance is being improved, and the court system is being restructured toward more efficiency and fairness. The judiciary applies laws, while the NA, the Communist Party of Vietnam, and the Government are vested with the power to interpret and implement laws. Those two documents demonstrate the strong commitment of Vietnam to expand and broaden the legal and judicial reform

3 Vietnam National Assembly, "The 2013 Constitution of the Socialist Republic of Vietnam", (2013), online: <http://vietnamlawmagazine.vn/the-2013-constitution-of-the-socialist-republic-ofvietnam-4847.html> Articles 69 to 71 .

4 Ibid.

5 Huong Phan \& Huong, "The Role of Vietnamese Government in Legislation - in Comparison with Japan” (2014) 11 Center for Asian Legal Exchange, Nagoya University (CALE Discussion Paper) 15.

6 Ibid.

7 Resolution 48-NQ/TW on Legal System Development Strategy to 2010 with a Visions to 2020 (LSDS), and Resolution 49-NQ/TW on Judicial Reform Strategy for the Period until 2020 (JRS). 
agenda, by tackling the pressing need to enhance legal awareness and access to justice and ensure the comprehensive implementation and enforcement of laws. These two strategies have clearly set out the reform agenda for the legal and judicial sector and remain the key guiding policy documents for legal and judicial reform as well as for the programming and partnership building between Vietnamese law-related agencies and international development partners. In light of this objective, the judicial reform is implemented according to 4 basic orientations including (i) perfecting the criminal, civil institutions and judicial procedures; (ii) reforming the organizational structure of judicial institutions and complementary judiciary institutions centered at courts and breakthroughs which were intensified in democratic litigation; (iii) building and improving the quality of the judiciary and judicial supplementary staff, particularly State officials having judicial titles; and (iv) renovating and strengthening the Party's leadership and the citizen supervision to judicial activities. ${ }^{8}$

Important changes have also been made to state structures, in particular through the adoption of the 1992 Constitution, which incorporates human rights guarantees. An effective legal system, ${ }^{9}$ which is respected by the people as an instrument that helps structure and facilitates the fair, orderly, and effective functioning of society, is a crucial element for balanced development. Numerous legislative amendments have been introduced, including reforms to the criminal justice system, especially amendments to the Criminal Procedure Code in 2003 and 2009, and the Criminal Code in 1999 and 2009. Other amendments are planned according to the legislative agenda of the NA. Whilst these new laws represent certain steps towards a fair, effective and rights-protecting justice sector, much work remains to transform the laws into reality so that they can play a role in guaranteeing rights, gender equality and justice in Vietnam.

Despite challenges related to slow implementation, those two strategies are at the core of Vietnam's partnership-building efforts with international development partners, and in fact, those two strategies have made tremendous efforts in developing a legal system to facilitate economic reforms, international integration and the strengthening of a rule-of-law state. Concurrently, the capacity of key legal and judicial institutions such as the NA, the Ministry of Justice (MOJ), the judiciary, and the procuracy has been importantly strengthened. Importantly, many measures have been introduced to realize political, civil, economic, social and cultural rights, however, further development needs to be made in local capacity building, enhancing people's access to justice, and enabling an environment for business and

8 Ngo Thi Hai Anh, "Đẩy mạnh cải cách tư pháp nhằm xây dựng và hoàn thiện nhà nước pháp quyền xã hội chủ nghĩa / Promote judicial reforms to build and perfect the socialist rule of law state” (2019) State Management Journal, online: <https://www.quanlynhanuoc.vn/2019/12/ 12/day-manh-cai-cach-tu-phap-nham-xay-dung-va-hoan-thien-nha-nuoc-phap-quyen-xa-hoi-chunghia-3/>.

9 The term "legal system" in Vietnam used here would cover the following five components:

- $\quad$ Legal framework of normative documents.

- Law-making process and institutions.

- Law implementation, dispute resolution institutions including courts.

- Legal information system; and finally.

- Legal education and training system. 
entrepreneurship development. Decisive actions are required to fight corruption, deal with drug abuse, illicit trafficking, including human trafficking, smuggling of migrants, money laundering and other crime-related problems, as well as for the enhancement of the role of the media. Regarding human rights, Vietnam has ratified many human rights core conventions. As Ngo T.M. Huong, Vu Cong Giao \& Nguyen Minh Tam showed that the legal changes regarding human rights reflected the profound global economic integration of Vietnam via WTO accession in 2005 in which Vietnam needed to meet requirements for WTO membership. Human rights really came into practice, driving changes in many domestic laws. To comply with WTO rules, Vietnam also needed to implement human rights commitments. All of these moves called for internal reforms in workforce management and workers' rights. ${ }^{10}$

In 2013, the NA adopted a further revised constitution, which reinforces its commitment toward a socialist law-based state, predicated on a unification of powers and strong political leadership under one political party, and toward the institutionalization of human rights in conformity with the international human rights norms and instruments to which Vietnam is a party. Many legal normative documents related to the implementation of the provisions of the 2013 Constitution are in the pipeline for review and revision such as the Civil Code, the Civil Procedure Code, the Criminal Procedure Code, the Law on Promulgation of Legal Normative Documents and many other laws on organization and operations of legal and judicial institutions. In fact, the 2013 Constitution and the 2015 Law on Promulgation of Legal Normative Documents constitute vital documents in the attempt to further the rule of law in Vietnam. They formally designate the NA (and its Standing Committee) as the principal producers of laws, ordinances and resolutions and stipulate that these instruments are formally superior to instruments enacted by other agencies. Institutional frameworks have started to be reviewed and strengthened as a necessary step to ensure that public service delivery would match the challenges of the rapidly growing socio-economic set up, including transparency and accountability mechanisms. Today, this institutional reform and other legal and judicial reform processes become more relevant as Vietnam enters the group of lower middleincome countries and aims to achieve status of industrialized country in 2020. Among the central themes of this reform process, is the wish to create a society governed by the rule of law. Transparency, democratization and substantial legal reform are essential in this context.

At the same time, legal reform is underway in Vietnam with high priority given to the economic sector for accession to international commitment, increasing foreign investment and implementation of the free trade agreements (FTAs). This means nearly all the laws and regulations have to be revised, changed or replaced with new ones. In recent years the NA has become more active. The ministers are now more accountable to the NA. The NA has also amended legislation. In addition, several UN agencies and some bilateral have made significant efforts to support parliamentary consultations and policy debates such as WTO accession, gender

10 Ngo Thi Minh Huong, Giao Cong Vu \& Tam Minh Nguyen, "Asian Values and Human Rights: A Vietnamese Perspective” (2018) 2:1 Journal of Southeast Asian Human Rights 314-316. 
mainstreaming, population and health, HIV/AIDS, public administration reform, parliamentary work on the fight against corruption, legal reform and improvement of representative and legislative capacity. A policy dialogue has been developed between the donor community and the NA for a significant period of time within the abovementioned framework. This dialogue has been based on Vietnam's strong commitment to streamline and rationalize the legislative process, reinforce the grassroots democracy initiative and improve effectiveness of the Local People's Councils.

Legal reform has been pursued with considerable energy and success in Vietnam in recent years, and the country has adopted numerous laws and policies to modernize its administrative and judicial systems. These would, if properly implemented and enforced, significantly contribute to greater efficiency in governance and improved protection of individual and collective rights. At the same time, the justice sector reform has been on slower progress due to structure, organization, capacity, and other difficulties within key justice sector institutions. As a result, the implementation lags behind, causing adverse effects to individual citizens, groups, private entities, state institutions and other sectors in society. Members of vulnerable and marginalised groups (such as the poor, women, children, LGBTs, and people living in rural, mountainous and remote areas) are likely to be the most affected. To remedy these problems, the Judicial Reform Strategy calls for improvement of criminal policies and procedures, a clear distinction between administrative and judicial functions (including safeguarding the independence of judicial authorities and officials in exercising their judicial tasks within Vietnamese constitutional and political parameters), introduction of adversarial litigation modalities, restructuring the district courts, publication of judgments, restructuring of the mandate of the procuracy in line with the restructuring of courts, improving the quantity and quality of practicing lawyers and creating a self-regulating bar.

Vietnam is a lower-middle-income country that has climbing the ladder of the Millennium Development Goals (MDGs) to the Sustainable Development Goals (SDGs) and has made great strides towards industrialization and integration into a global economy. ${ }^{11}$ The transition from central planning to a market economy started in 1986 with the reforms and has advanced much, but it is not yet complete. To ensure achievement, Vietnam has to tackle challenges such as modernizing, strengthening, and developing public institutions, including the NA. Some of the challenges to advance this objective consist of better access to adequate information; putting in place mandates and supporting them with processes, tools, and guidelines for more effective internal operations; leveraging external partnerships to contribute to inclusive policymaking; and investing in capacity building and appropriately tailored technical solutions. Furthermore, to attain success, the NA requires a constitutional blueprint with principles that lend themselves to institutional renovation in the legislative branch and facilitate rule of law, accountability, transparency, and oversight; leadership and political will; and well-targeted and timely international technical collaboration.

11 World Bank \& Ministry of Planning and Investment of Vietnam, Vietnam 2035: Toward Prosperity, Creativity, Equity, and Democracy (2016). 
A continued lack of accountability, and public participation in the promulgation of laws and regulations that impact social and economic development remains a central challenge. At a minimum, not leaping at a more efficient, transparent and accountable approach to governance will hinder Vietnam from realizing the huge potential that so many have recognized it possesses. Other constraints include the weak co-ordination of external assistance of legal development activities. Also, legal education and professional training and re-education face major constraints. Moreover, inadequate attention has been given to legal implementation measures, e.g. training of judges, legal activities awareness (e.g. education and dissemination), and resource allocation strategy. Currently, the focus is primarily on academic training rather than to equip trainees with legal and practical professional skills such as legal analysis and problem-solving, legal writing and advocacy skills.

A rights-based approach to legal reform implies that legal frameworks should be developed with civil society actors, should catalyze social policies and promote the establishment of a rule of law. As the country takes up middle-income status, addressing gaps in requirements for inclusive decision-making, accountability, transparency and efficiency become more critical for the sustainability of the reform and development process. The enactment of the 2015 Law on Promulgation of Legal Normative Documents has enabled the introduction of public consultation mechanisms into the legislative process. Concerted efforts from NGOs and other civil society actors are integral in addressing this gap.

\section{THE CHALLENGES OF REFORMING LEGAL SYSTEM ON THE ASSURANCE OF HUMAN RIGHTS STANDARDS IN VIETNAM}

The first challenge is that Vietnam needs to continue ensuring the harmony between national laws and international human rights laws to bring Vietnam's laws closer to international human rights standards."

Right from the first Constitution of Vietnam in 1946, the fundamental rights and obligations of citizens play a very important role in the document. After that, these provisions gradually improved and supplemented in the Constitution of 1959, 1980 and 1992 and now is 2013. As Ngo T.M. Huong, Vu Cong Giao \& Nguyen Minh Tam indicated that until 1992, the Constitutions were still heavily influenced by Marxist-Leninist ideology and a socialist human rights tradition was established whereby human rights were equated to the concept of citizens' rights. Opposing ideas and ideologies emerged when the 1946 Constitution was being developed. The 1959 Constitution was an extension of the 1946 Constitution as it contained 21 articles related to rights and duties of citizens. The 1980 Constitution was developed for a unified Vietnam, which inherited and was built on the two previous constitutions. It had 29 Articles specifying citizen rights. Provisions on human rights were only placed in Chapter III of the 1959 Constitution and in Chapter V of the 1980 Constitution and many rights were omitted. Moreover, even within that narrow socialist legal model, cultural and economic rights were emphasized more than 
individual civil and political rights. ${ }^{12}$ Also, in line with those authors' opinion, the 1992 Constitution for the first time provided a concept of human rights and used the term "human rights". Other human rights in the field of society, economy and culture were also recognized and the right to private ownership was restored. However, the language which described human rights and the 1992 Constitution did not fully reflect the international concept of human rights. They seemed as "gifts" of the State, not natural rights. ${ }^{13}$

The Constitution of 2013 is a great step forward in the perception and awareness of the Party and Government about the position and role of Constitution in the recognition, respect and assurance of human and citizen's rights. ${ }^{14}$ Giao Cong Vu \& Kien Tran agreed that provisions relating to human rights and citizens' rights constituted most of the amendments in the 2013 Constitution. They also received much public attention and were the subject of 7,383,962 (28\%) out of 26,091,276 suggestions raised to the Amendment Committee. The location and title of the chapter on human rights and citizens' rights was significantly altered..$^{15}$ Many rights originally considered as citizens' rights in the 1992 Constitution, are now recognized as human rights in the 2013 Constitution. ${ }^{16}$ The provisions of human rights in Chapter II of the 2013 Constitution (on the basis of amending, supplementing and rearranging chapter $\mathrm{V}$ of the 1992 Constitution) show a change in perception, considering the people as the supreme subject of the Government. In addition, human rights are not only mentioned in Chapter II but in many other chapters, for example the chapter on Government, People's Procuracy, People's Court.

One of the new provisions of the 2013 Constitution is the stipulation of the principle of limiting rights which is "Human rights and citizen's rights can only be restricted by laws in case of necessity for reasons of national defence, national security, social order and safety, social morality and public health". The provisions of Clause 2, Article 14, meet the basic criterion of arbitrarily limiting human rights and citizenship; These rights are restricted only in urgent cases related to national security and social order and safety. However, in Vu Cong Giao \& Kien Tran's opinions, there are researchers believed that the 2013 Constitution has regulations on limiting rights are not really reasonable. Article 14 stipulates that human rights, civil rights can only be restricted under the provisions of law in case of necessity for reasons of national defence and security, while Article 15 states that "the exercise of human rights and citizenship must not infringe upon the interests of the nation, the nation, the legitimate rights and interests of others". This easily creates power abuse from state agencies in limiting human rights, ${ }^{17}$ etc. The 2013 Constitution generally provides more specific concise and clearer provisions on human rights and citizens'

12 Huong, Vu \& Nguyen, supra note 10.

13 Ibid.

14 Ministry of Justice, "Ưu tiên ban hành các luật về quyền con người / Priorities on issuing human rights laws”, online: <https://moj.gov.vn/tctccl/tintuc/Pages/tin-tuc-hoat-dong.aspx?ItemID=260> accessed on 16 July 2020.

15 Giao Cong Vu \& Kien Tran, "Constitutional Debate and Development on Human Rights in Vietnam” (2016) 11:2 Asian Journal of Comparative Law 235-262.

16 Ibid.

17 Ibid. 
rights in the comparison with the 1992 Constitution which has facilitated the implementation of these provisions in practice. ${ }^{18}$

Accordingly, the Constitution of 2013 has amended and supplemented to specify clearly and sufficiently human rights such as: right to equality, non-discrimination before the law (Article 16); be protected against torture, violence, coercion, corporal punishment or any form of treatment harming his or her body and health and offence against honour and dignity (Article 20.1), the right to protect private life (Article 21) ${ }^{19}$. Some new human rights were also recognized in the Constitution including the right to life (Article 19), the right of citizen not to be expelled or extradited to another country (Article 17), the right to legal residence (Article 22), the right to social security (Article 34), the right to marry and divorce (Article 36), the right to experience and approach cultural values, to take part in cultural life, and to use cultural facilities (Article 41), the right to determine one's nationality, to use one's mother language, and to select the language of communication (Article 42), and the right to live in a clean environment (Article 43). These amendments were made "in order to affirm the important value and role of human rights and citizens' rights in the Constitution and to demonstrate that the CPV and the State will consistently respect, preserve, and protect human rights and citizens' rights". ${ }^{20}$ Although there are still certain restrictions in some civil and political rights such as the right to freedom of association, the right to assembly, the right to protest, and the right to vote in the referendum. The right to vote in the referendum was delayed until the NA law-enacting or until the Government issues decrees to guide the implementation.

In order to implement the Constitution 2013 and international commitments on human rights, during the periods from 1986 to 2009, Vietnam has reviewed, issued or amended about 13,000 legal documents and sub-laws; ${ }^{21}$ from 2014 to 2018, Vietnam supplemented, amended or issued 96 new laws and or ordinance relating to ensuring human rights and citizen's rights. ${ }^{22}$ Some important laws were passed by the NA include: Law on Organization of the People's Procuracy 2014, Law on Organization of People's Courts 2014; Penal Code 2015, Criminal procedure code 2015; Civil Code 2015, Civil Procedure Code 2015; Law on Administrative procedure 2015, Law on Referendum 2015; Law on Beliefs and Religions 2016, Children's Law 2016, Press Law 2016, Cyber Security Law 2018, etc. A number of laws were first promulgated to promptly institutionalize human rights and citizen's rights provisions of the Constitution 2013 such as the Law on Referendum 2015 and the Law on Access to Information 2016.

Along with the efforts to improve the national legal system, Vietnam also strengthened its international cooperation on human rights. Vietnam's participation

18 Ibid.

19 National report - Universal periodic review on human rights assurance in Vietnam, 3rd period, by Ministry of Foreign Affairs (2020).

20 Uong Chu Luu, nhũ̃ng nội dung cơ bản của Hiến pháp Nước Cộng hòa xã hội chủ nghĩa Việt Nam / Main Contents of the Socialist Republic of Vietnam's Constitution (Quangtri Department of Natural Resources and Environment, 2014).

21 National report - Universal periodic review on human rights assurance in Vietnam, 2nd period, by Ministry of Foreign Affairs (2020).

22 Ministry of Foreign Affairs, supra note 19. 
in international and regional human rights bodies, such as the United Nations Human Rights Council ${ }^{23}$ and the Association of South East Asian Nations Intergovernmental Commission on Human Rights, ${ }^{24}$ as well as Vietnam's implementation of the Universal Periodic Review, all of which have improved Vietnam's enforcement mechanisms for constitutional rights. ${ }^{25}$ In addition to the treaties developed by the United Nations, Vietnam also ratified numbers of specialized legal documents of ILO as well as treaties within the ASEAN region. ${ }^{26}$ For a country with many difficulties and low income like Vietnam, it has not been easy to ratify and fulfil the large number of obligations stipulated in the international human rights treaties. However, stemming from a consistent policy which respects human rights, Vietnam is expressing the determination and responsibility for one of the great problems of humanity that is protecting and promoting human rights. A report of United Nation Development Programme (UNDP) in 2018 showed that Vietnam is in the Medium High category in terms of Human Development Index (ranking at 116 out of 189 countries) and Gender Equality Index (ranking at 67 out of 160 countries). Besides, according to a report of World Bank (WB), the poverty rate in Vietnam continues to decline, especially among ethnic minorities, with a sharp drop of $13 \%$, the greatest reduction in the last decades. ${ }^{27}$ Generally, through the reforming process to improve the legal system, the principles and standards on human rights in international human rights laws have been incorporated into the national legal system of Vietnam which create an important legal basis to protect and enforce human rights commitments in practice.

However, due to the time-consuming process of legislation, the current legal system has also shown some unreasonable and contradictory factors and has not been able to keep up with the requirements to ensure the rights in practice. Some rights are recognized in the Constitution but not yet institutionalized in timely manner which creates a phenomenon called "suspended" rights with little actual effect, such as the right to association and the right to protest. ${ }^{28}$ The legislative process does not

23 Office of the High Commissioner, United Nations Human Rights, "OHCHR | HRC Membership of the Human Rights Council, 1 January - 31 December 2020”, (10 September 2020), online: Office of the High Commissioner, United Nations Human Rights <https:/www.ohchr.org/EN/HRBodies/HRC/Pages/CurrentMembers.aspx>.

24 Vietnam has been a member of the ASEAN Inter-governmental Committee on Human Rights (AICHR) since 2009. See ASEAN Intergovernmental Commission on Human Rights, "About AICHR”, online: <https://aichr.org/>.

25 Vu \& Tran, supra note 15.

26 Minh Duyen, "Việt Nam đạt nhiều thành tựu về quyền con người / Vietnam's achievements on human rights"”, (16 July 2020), online: Trang thông tin điện tư - Hội đồng lý luận TW <http://hdll.vn/vi/nghien-cuu---trao-doi/vie\%CC\%A3t-nam-da\%CC\%A3t-nhie\%CC\%80utha\%CC\%80nh-tu\%CC\%A3u-ve\%CC\%80-quye\%CC\%80n-con-nguo\%CC\%80i.html>.

27 TTX, "Việt Nam tiếp tục hoàn thiện pháp luật bảo đảm quyền con người/ Vietnam continues to improve laws to ensure human rights", (2019), online: <http://tuyengiao.vn/dan-so-va-phattrien/viet-nam-tiep-tuc-hoan-thien-phap-luat-bao-dam-quyen-con-nguoi-125825>.

28 Tran Thi Hoe, "Nhà nước Việt Nam đối với việc bảo đảm quyền con người trong điều kiện hội nhập quốc tế hiện nay / Vietnam’s government and the assurance of human rights in the current context of international integration” (2016) 85:4 Human research Journal, online: $<$ https://vass.gov.vn/nghien-cuu-khoa-hoc-xa-hoi-va-nhan-van/nha-nuoc-viet-nam-doi-voi-viecbao-dam-quyen-con-nguoi-trong-dieu-kien-hoi-nhap-quoc-te-hien-nay-74>. 
really appreciate the right - based approach with the fundamental principles that citizens are entitled to participate in the decision-making process affecting their lives. The ineffective law enforcement in protecting the rights of vulnerable groups, ${ }^{29}$ etc. is also a problem. According to Tran Thi Hoe, when the country has entered the development stage, along with the increase of economic resources and educational level in society, there will be higher demands on ensuring human right standards recognized by international laws. Additionally, the rapid development of information technology has created new possibilities for protecting human rights as well as emerging demands for new rights such as the right to live in a clean environment and the right to social security, right to private ownership ${ }^{30}$.

Furthermore, up to now Vietnam signed or has been negotiating 17 free trade agreements (FTAs) with counterparts. Many of these FTAs, especially CPTPP and EVFTA, are classified as new generation FTAs. Labor standards are also considered as the factor that made the quality and differences in the new-generation FTAs. ${ }^{31}$ It is worth noting that the new-generation FTAs do not set labor standards, but only reaffirm labor standards in eight Conventions of the International Labor Organization (ILO) ${ }^{32}$ Currently, Vietnam has ratified 5/8 basic ILO conventions. Vietnam's unapproved conventions include Convention 87 (Freedom of Association), Convention 98 (Right to Collective Bargaining) and 105 (Against Forced Labor). Joining new generation FTAs such as CPTPP and EVFTA means that Vietnam will have to consider ratifying the three remaining conventions and integrating them into the national legal system. In fact, when the new generation trade agreements take effect, Vietnam and other countries will start to welcome a wind of change in the investment and trade development brought by those Agreements. However, one of the main challenges that have to be addressed is the emergence of organizations/associations which are not members of the Vietnam Trade Union. This creates pressure on representative organizations of traditional Vietnamese workers as well as the current regulations on associations in Vietnam. ${ }^{33}$ Therefore, reviewing the regulations on associations is one of the most important actions to concretize the provisions of the Constitution and also necessary for Vietnam to implement its commitments in related international documents. All these issues have set new

29 Ibid.

30 Ibid.

31 WTO Center VCCI, "Yếu tố lao động trong các FTA thế hệ mới / Labor factor in new generation FTAs", online: <https://rungtamwto.vn/hiep-dinh-khac/13303-yeu-to-lao-dong-trongcac-fta-the-he-moi>.

32 These are Convention 87 and 98 on freedom of association and collective bargaining; Conventions 29 and 105 on the right to freedom from forced or compulsory labor; Convention 138 and 182 Eliminate Child Labor; Conventions 100 and 111 on the Elimination of Discrimination in Employment and Occupation

33 Article 13.4, Clause 2, EVFTA stated that: "2. Each party affirms its commitments, consistent with its obligations in the ILO and the ILO Declaration on fundamental principles and rights at work [...], to respect, promote and effectively implement principles relating to fundamental labor rights, namely: (a) freedom of assembly and effective recognition of the right to collective bargaining; [...] ". Article 19.3 in Chapter 9 of the CPTPP stipulates: "1. Each party shall adopt and maintain laws and regulations, and implement such laws and regulations in their respective countries, the following rights as loved in the ILO Declaration: (a) Freedom of assembly and effective recognition of the right to collective bargaining [...] ". 
requirements for the process of reforming and improving legal system of Vietnam in the upcoming time.

"The next challenge is that Vietnam needs to continue to refine regulations to ensure the rights of vulnerable groups under the impacts of the integration process."

In addition to ensuring basic human rights standards for all, in the coming time, Vietnam needs to continue to define prioritised policies for vulnerable groups in society such as women, children, LGBTs people, people with disabilities etc. in which, migrant workers are also one of the groups that need to be protected by the national laws due to their "vulnerable" factors.

Vietnamese migrant workers are a vulnerable group, they face high risks of physical and mental abuse, and many challenges throughout the migration process to work abroad. When working abroad, Vietnamese workers have to encounter social stigma and discriminatory attitude towards foreign workers as well as difficulties in accessing legal procedures. They have been subjected to exploitation, beaten and mistreated, especially for Vietnamese who are working unofficially, or by illegal migration or by overstaying after the legal migration contract has expired.

The latest report of the Ministry of Labor, Invalids and Social affairs (MOLISA) of Vietnam shows that currently, more than 500.000 Vietnamese people are working under abroad contracts in more than 40 countries and territories around the world, with about 30 different occupations that vary from unskilled labor to skilled and expert labors. ${ }^{34}$ However, in addition to economic benefits, Vietnamese workers working abroad are also facing many difficulties in the host country such as social stigma and discrimination against foreign workers, accessing to legal procedures (contracts, work permits). Especially for Vietnamese workers who are undocumented immigrants, or illegal migrants or legal migrants but stay after the contract expires, they are not protected by law and easily become victims of criminal groups. A typical case is the incident that 39 Vietnamese citizens were found dead in a container on their way to illegally immigrate into the UK in late 2019.

Although Vietnam has not been a member of the UN Convention on the Protection of the rights of all migrant workers and members of their families, Vietnam has been acknowledging very early on the rights of Vietnamese abroad workers in the national legal system. The 2013 Constitution clearly states that "Citizens have the right to free movement and residence within the country, and the right to leave the country and to return home from abroad". And "Overseas Vietnamese is an inseparable part and a resource of the community of Vietnamese nationalities... The protection of the legitimate rights and interests of Vietnamese citizens and legal entities in foreign countries is extremely necessary, demonstrating the State's

34 Overview report on the migrating situation of Vietnamese citizen to foreign countries, by European Union, Consular Department - Ministry of Foreign Affairs and International Organization on Migration (Hanoi, 2011).

35 Vietnam National Assembly, supra note 3, art. 23. 
responsibility towards citizens..." ${ }^{36}$ To implement the 2013 Constitution, the issue of the rights of Vietnamese workers abroad was concretized in documents such as: Law on Vietnamese Nationality 2008 (amended and supplemented in 2014); Law on Overseas Representative Offices of the Socialist Republic of Vietnam 2009; Law on Vietnamese workers working abroad under contracts 2006, Law on Human Trafficking Prevention and Control 2011, Penal Code 2015 (revised in 2017); etc. there are also agreements on regulations on land border management between Vietnam and bordering countries. Despite the efforts to recognize the rights of Vietnamese workers abroad, in general, the legal system of Vietnam on migration still lacks policies and provisions to ensure the legal rights and interests of Vietnamese citizens during the migration process (before leaving - while in the country - upon repatriation and reintegration). It can be seen that the system is having a gap on provisions relating to types of migration among Vietnamese abroad workers. Most of them have not been internalized into the national laws, scattered in subordinate documents, thus, there exists overlaps, lacks comprehensive cooperation, ineffectiveness and even causes difficulties for the management of authorities. ${ }^{37}$ The current provisions relating to the rights of migrant workers without legal documents are still general and lacklustre, while in practice, the number of illegal Vietnamese worker oversea is very high, the reintegration process for them have not been specifically legislated. Additionally, current migration policies pay little attention to gender issues and have not mainstreamed gender equality with female migration issues in Vietnam.

In summary, currently, Vietnam still lacks an effective policies and legal system in ensuring the rights of migrant workers. This makes migration of worker becomes unsafe and put Vietnamese citizens at risk when working, studying, living and residing abroad. Therefore, it is urgent and should be prioritised to improve the provisions of the law to better ensure the legal rights and interests of Vietnamese migrant workers working abroad. Migration (whether legal or undocumented) will be protected and given the opportunity to contribute to the national socio-economic development.

"Environmental rights need to be addressed and improved in the context that climate change is becoming a danger to all people's lives."

According to the most recent report of the Ministry of Natural resources and environment, climate change has affected Vietnam since the country's economy began to recover and develop. In the period from 1958 to 2014, Vietnam coped with the impacts of climate change such as annual increasing temperature, rising sea level, abnormal rainfall and many other problems. Climate change also negatively affects the exercise of the right to live in a clean environment through the enjoyment of the related rights consisting of the right to life, the right to food, the right to drinking water, the right to health care, the right to adequate accommodation and other rights. ${ }^{38}$

36 “Resolution on overseas Vietnamese, date issued Mar. 26, 2004, No. 36-NQ/TW.”, online: <http://quehuongonline.vn/van-ban-phap-luat/resolution-no-36-nqtw--march-26-2004-by-thepolitbureau-on-the-overseas-vietnamese-affairs-6866.htm>.

37 Ibid at 64-70.

38 Asian Development Bank, Viet Nam: environment and climate change assessment (2013). 
Before the Constitution of 2013, the right to live in a clean environment was not recognized as a constitutional right, but only stipulated in other laws and documents. By acknowledging that "Everyone has the right to live in a clean environment" (Article 43 of Vietnam's Constitution 2013), Vietnamese government does not only define the right to live in a healthy environment as a constitutional right but also considers protecting the environment is the responsibility and obligation of every organization, business, household and individual. ${ }^{39}$ Vietnam also recognizes the importance of protecting environment and climate change response to ensure economic growth, social security, children's rights, gender equality and biodiversity conservation. The main goal is to ensure a clean and healthy living environment for people. ${ }^{40}$ Also, in this Constitution, Vietnam determined that environmental protection is one of the priorities in the national policy - making process and socio-economic development. ${ }^{41}$ People have right to access information on environment ${ }^{42}$ provided by governmental agencies, businesses, ${ }^{43}$ or they can actively request state agencies and other bodies such information. ${ }^{4}$

In addition to recognizing the right to live in a clean environment in 2013 Constitution, the Government of Vietnam has set requirements for the process of constructing policies and laws to ensure this right such as: ensuring human rights in the policies and laws on climate change has to link to the development and planning of environment, ${ }^{45}$ formulation of socio-economic strategies ${ }^{46}$ and planning and sustainable exploitation of natural resources, ${ }^{47}$ etc. These provisions are specifically in Law on Environmental Protection 2014, Law on Water resources 2012, Law on Energy Efficiency and Conservation 2011, Law on Forest protection and development and many other laws.

Therefore, despite the legal aspects and techniques to protect basic elements of a clean-living environment are systemized quite sufficiently, they are still weak in practice. Polluted soil, water, air and toxic food show that the level of assurance of the right to live in a clean environment in Vietnam is relatively low. ${ }^{48}$ The evidence is a series of environmental pollution cases have been revealed recently, which led to severe consequences on the economy, ecology and life of people, including serious

39 Vietnam National Assembly, supra note 3, Article 43; The Law on Environmental Protection 2014, article 4(1).

40 Ministry of Foreign Affairs, supra note 19, para 10 at article 4(2).

41 Vietnam National Assembly, supra note 3, Article 50 and 63.

42 Ibid, Article 25; Ministry of Justice, supra note 14.

43 The Law on Environmental Protection 2014, supra note 39, Article 131.

44 Ibid, Article 145, 146.

45 Ibid, Article 8 to Article 12.

46 Ibid, Clause 8 Article 15, Article 21; Point c Clause 3 Article 10 Decree no 18/2015/NĐ-CP on $14 / 02 / 2015$ by the Government on planning and environmental protection, strategic environment evaluation, environmental impact assessment and environmental protection planning.

47 Ibid, Clause 1 Article 35, Article 38.

48 Đặng Công Cường, "Pháp luật bảo đảm quyền được sống trong môi trường trong lành Việt Nam / Laws to ensure the right to live in a healthy environment in Vietnam" Công Thương (10 May 2020), online: <http://tapchicongthuong.vn/bai-viet/phap-luat-bao-dam-quyen-duoc-songtrong-moi-truong-trong-lanh-o-viet-nam-71531.htm>. 
incident of marine pollution caused by Formosa Ha Tinh company, the issue of direct discharge of untreated waste of Vedan Company into Thi Vai River (Dong Nai province) which accounted for $80 \%$ - $90 \%$ reasons for the pollution situation in this river. ${ }^{49}$ According to the report on environmental protection in 2019 by the Ministry of Natural Resources and Environment, as of December 2019, 171 companies in Vietnam still discharged into environment causing serious pollution situation and have not conducted effectively measures to tackle pollution. ${ }^{50}$ Additionally, there are several factors causing environmental pollution such as (1) the rapid urbanization rate, constantly increasing number of vehicles, (2) improper awareness of the importance of environmental protection and (3) the close connection among three factors of the sustainable development process which are: environmental protection, economic development and social development. This situation raises the need to improve the legal framework on environmental protection and enhance awareness of all classes of people in environmental protection and considering protecting environment as protecting their own rights and lives.

"The final point is on improving mechanism, capacity and responsibilities of State agencies in ensuring human rights and citizens' rights"

The next point of the legal reform process is enhancing the responsibility of State agencies, individuals and organizations to ensure human rights; focusing on reforming organizational structure and operation of institutions to protect human rights, avoiding stagnation and overlap in functions and duties of agencies, specifically concentrating on reforming the monitoring function of the NA in issuing laws and implementing international human rights treaties.

In Vietnam, legislative oversight is a means for holding the Government and other state actors accountable for their actions and ensuring that it implements policies in accordance with the laws and budget passed by the legislature. ${ }^{51}$ In recent years, the NA has emerged as a respected institution in its efforts to strengthen its legislative, oversight and representation functions. Laws submitted to this legislative body are undergoing lengthier and more in-depth discussion than in the past, and increased attention is being paid to the development of monitoring and supervision mechanisms. Effective oversight is conducted to ensure transparency and openness; encourage a policy-making environment where actions of government and other actors are debated and receive public input; scrutinize government policies to ensure they have been implemented adequately and have obtained the desired impact; provide for financial accountability, highlight the areas where there is waste in publicly-funded services, seeking effectiveness and efficiency of government

49 Tuyet Nhung, "Điểm mặt” 10 công ty gây ô nhiễm nghiêm trọng nhất ở Việt Nam / 'Pointing out' 10 companies that caused serious pollution in Vietnam”, (3 August 2016), online: <https:/www.thiennhien.net/2016/08/03/diem-mat-10-cong-ty-gay-o-nhiem-nghiem-trong-nhato-viet-nam/>.

50 Báo cáo Hiện trạng Môi trường quốc gia 2019: Nhận diện nguồn gây ô nhiễm / Report on national environmental situation 2019: Identify the polluting sources, by Yen Thi (Báo Tài nguyên \& Môi trường, 2020).

51 The National Assembly "Law on Monitoring Activities of the National Assembly and People's Councils" (2015) 
expenditure, and upholding the rule of law; and contribute to monitoring policies to ensure citizens' rights are protected within the framework of the Constitution. The 2013 Constitution implies reinforcement of the role of the NA through providing for a more democratic representative composition, and more focus on the role of a lawmaking entity.

In recent years, the NA has become increasingly active and influential in setting national priorities. Although most legislation still originates from the Government, such legislation has come into sharper focus and is now more hotly debated in the NA. The NA has a strong constitutional mandate in relation to national policy decisions and is showing increasing initiative in this area. Although having wide constitutional powers, the NA is not necessarily so powerful in practice, nor is its capacity up to the requirements to assume such a centralized power. The majority of the deputies of the NA are part-time deputies who gather to discuss the business of the NA only for two 30-day sessions a year. In addition, the legislative body has faced numerous challenges which constrain its ability to meet growing expectations to orientate complex growth processes in a lower-middle-income country context, including limited time for deliberations; limited availability of independent, qualitative in-house policy analysis capacity and resources for deputies and committees, with its research body, the Institute for Legislative Studies (ILS) which was established by the NA Standing Committee in 2008 as a national leading authority on legislative studies, few (about 30\%) full-time deputies; high turn-over among deputies and the potential conflict of interests of part-time deputies are challenging higher effectiveness of this law-making body and will heighten the need for more effective participation by citizens, media and CSOs in legislative processes.

At present, oversight activities of the NA are implemented through (i) procedures for supreme supervision activities of the NA at the meeting, (ii) procedures for supervision activities of the Standing Committee of the NA; (iii) monitoring and supervising operation process of Councils and committees of the NA; (iv) supervision process of the delegation of parliament and parliament deputies. ${ }^{52}$ Despite continuous improvement and unification through different stages, the oversight of the NA still has certain limitations and challenges. The lack of oversight on governmental activities leads to the need for a more effective scrutiny process. The Q\&A component of the NA's regular sessions continues to be an important means for the NA to demand answers from members of the Government on issues affecting the public interest, but there tends to be little follow up. Committed

52 According to Article 7 of the Law on supervision activities of the National Assembly and People's Councils in 2015, the NA can supervise the operations and activities of the executive by:

- Examining reports of main agencies on the state structure (reports of the NA Standing Committee, the Government, the President, the Supreme People's Court, the Supreme People's Procuracy ;

- Examining the normative legal documents of competent agencies and individuals in the main agencies with signs contrary to the Constitution, Laws and Resolutions of the NA;

- $\quad$ Considering answering the questions of individuals elected or approved by the NA;

- Establishing the ad-hoc committee to investigate a certain issue and review the Commission's investigation results report;

- Casting a vote of confidence. 
individual deputies have achieved successes in specific interest areas, but the paths they chose and the techniques they employ often rely on individual initiatives, rather than from a clear understanding of their powers or available mechanisms and methods for more effective oversight. With nearly three-quarters of the NA deputies replaced every five years, this may increase the risk that knowledge and experience that the previous the NA's tenure have gained will be lost.

The ability of the NA to perform the role of a check and balance on the executive and other state actors has also been strengthened. It has been playing increasingly active roles in external oversight, despite being constrained by high turnover. General elections will be held in 2021 to select deputies to the NA and the full-time membership is expected to increase. The NA and PCs have been strengthened by an expanded legal framework and have taken on an enhanced role in the law-making process and oversight. Political developments about the role of the NA and decentralization present great opportunities for realizing and monitoring the rights of children, women, ethnic minorities, etc., but all this place heavy demands on institutions which require strengthened capacity to deliver. Supporting the NA and its support structure by collaborating on interactive workshops and training is a key part of the development partners in Vietnam. Greater openness and more opportunities for citizens to participate in governance are needed to support Vietnam's long-term vision of becoming a modern industrialized society. The increasing role of the NA in reviewing legislation and policies and a gradually more incisive media have contributed to greater transparency in the country, but there are limits to dissent. The NA is recognized as having a key role to play in monitoring promotion and protection of human rights but could potentially play a stronger role in this regard, for example in relation to complaints and petitions.

These analyses show that the monitoring process of Vietnamese legal documents still have a "one-way" direction (subjective) since it lacks a legal body to evaluate the constitutionality and feasibility of the documents issued by the NA. Although Article 119 of the Constitution in 2013 states that the Constitution is the supreme law of Vietnam, any violations of the Constitution shall be dealt with. All state agencies and the people have responsibility to protect the Constitution because the Constitution is of the people, by the people, for the people. This can also be considered as a very special form of monitoring the implementation of the Constitution, however, this does not automatically apply to the laws and codes legislated by the NA. As analysed above, the NA plays the most important role in the law-making process in Vietnam, nevertheless, according to the Constitution, this right is to be extended to law enforcement agencies including Government and the Prime Minister, Ministers and heads of ministerial - level agencies. Of course, all documents issued by Government or other agencies are legally binding by the Constitution and laws enacted by the NA. In case they are contrary to the Constitution, the laws will be subject to the suspension and abolition order from Standing Committee of the NA. However, the question is how the post-legislative process will take place, especially in the context that Vietnam does not have a Constitutional Court to determine the constitutionality of current legal documents? This is truly a challenge and one of the important tasks that should be discussed in the near future. 


\section{CONCLUSION}

Despite the achievements in human rights field, the impact of international integration and the Fourth Industrial Revolution has made a lot of changes in the socio-economic situation which require the legal system in general and the human rights law in particular, to be improved and suitable with the current context. On the other hand, in the context of a socialist-oriented market economy, the social stratification has led and will lead to a stronger diversification of demands for human rights between social classes. This practice requires Vietnam to meet the increasing demands on human rights in different communities, and to continue to fulfil the obligation to ensure the essential rights, especially economic, cultural and social rights of vulnerable groups. In order to do so, Vietnam needs to keep reviewing all human rights provisions, removing outdated ones, revising and updating new provisions to fully recognize the fundamental rights of disadvantaged groups and the prominent rights such as environmental rights, right to personal safety in cyber environment, etc.

Notably, legal system reform needs to stress on the importance of human rightsbased approach in planning and implementing policies, laws, national strategies on socio-economic development issued by the Party and Government. Moreover, it is also recommended to further institutionalize and exercise civil and political rights, as they are the direct foundation for the right to life and development.

Regarding the reform of the State apparatus, it is necessary to improve the provisions relating to the monitoring and evaluation of the constitutionality of postlegislative documents. As mentioned above, Vietnam does not have a specialized agency capable of monitoring the legislative activities and assessing the feasibility of legal documents issued by the NA. Laws promulgated by the NA will be considered from the time they are drafted to ensure the legality and will be amended and supplemented after a process of application in life. The post - legislation scrutiny process is still quite faint and can create different perspectives regarding the effectiveness, practicality and updating of legal documents when applied to social life. From the above-mentioned fact, some researches have showed that Vietnam should consider establishing a special agency which has the function to monitor the legality of documents issued by the NA. It could be a new independent Committee of the NA or assigning the function of oversight for one of the NA's committees. In practice, it is inappropriate to set up an independent agency with the NA to implement oversight in Vietnam now because it would disrupt the position and unity of the NA as the highest state power authority of the country. Therefore, proposing an agency elected by the NA is more reasonable in the current context of Vietnam. With the two options which are given above, the author is inclined toward the first. It will be a special agency established by NA with the function of supervising and examining documents issued by the NA, the NA Standing Committee and other agencies, which will operate independently, objectively and only obey the Constitutional and law. Because the agency still belongs to the NA, therefore, to ensure its independence and objectivity, the NA needs to state clearly about its operating principles, personnel and finance issues to avoid all suspicions that the NA conducts the oversight process itself. 
Finally, it is recommended to strengthen educational methods for every citizen as well as civil servants in the political system about human rights and the responsibilities to protect human rights in order to change their mindsets and perceptions of human rights for all people regardless their social status. The correct perception will be the foundation for the right actions. In addition, it is also necessary to promote dialogue, international cooperation and increase Vietnam's participation in international human right institutions and forums. Thereby, Vietnam can actively introduce and share its experience with international counterparts on the process of ensuring human rights and be able to learn good lessons from them in order to improve policies, laws and implement appropriate measures.

\section{BIBLIOGRAPHY}

ASEAN Intergovernmental Commission on Human Rights, "About AICHR", online: <https://aichr.org/>.

Asian Development Bank, Viet Nam: environment and climate change assessment (2013).

Bùi Đức Hiển, "Về quyền được sống trong môi trường trong lành ở Việt Nam hiện nay/About the Rights to live in a healthy enviroment in Vietnam" (2011) 11 Journal of Law, online: </chi-tiet/ve-quyen-duoc-song-trong-moi-truong-tronglanh-o-viet-nam-hien-nay-28763.html>.

Bùi Sỹ Lợi, Tăng cường hiệu lực, hiệu quả hoạt động giám sát của quốc hội, hội thảo/strengthening the effectiveness and effectiveness of supervisory activities of the National Assembly (2015) in the conference "Vietnam National Assembly: 70 years of establishment and development”.

Đặng Công Cường, "Pháp luật bảo đảm quyền được sống trong môi trường trong lành Việt Nam / Laws to ensure the right to live in a healthy environment in Vietnam” Công Thương (10 May 2020), online: <http://tapchicongthuong.vn/bai-viet/phap-luat-bao-dam-quyen-duoc-songtrong-moi-truong-trong-lanh-o-viet-nam-71531.htm>.

Dinh Dung Sy, "Hệ thống pháp luật Việt Nam trong tiến trình đổi mới và phát triển đất nước" (2020) 401:1 Legal Research Journal, online: <http://www.lapphap.vn/Pages/TinTuc/210462/He-thong-phap-luat-Viet-Namtrong-tien-trinh-doi-moi-va-phat-trien-dat-nuoc.html>.

European Union, Consular Department - Ministry of Foreign Affairs and International Organization on Migration, Overview report on the migrating situation of Vietnamese citizen to foreign countries, by European Union, Consular Department - Ministry of Foreign Affairs and International Organization on Migration (Hanoi, 2011).

Hanoi University of Law, Giáo trình luật hiến pháp Việt Nam / The Constitution Law of Vietnam Textbook (Cong an nhan dan Publisher, 2014). 
Huong, Ngo Thi Minh, Giao Cong Vu \& Tam Minh Nguyen, "Asian Values and Human Rights: A Vietnamese Perspective" (2018) 2:1 Journal of Southeast Asian Human Rights 314-316.

Legal Commission of the National Assembly and UNDP, Báo cáo nghiên cứu về một số quy trình, thủ tục trong hoạt động của quốc hội/ Research report on a number of processes and procedures in the activities of the National Assembly, by Legal Commission of the National Assembly and UNDP (2012).

Luu Ngoc To Tam, "Chức năng của Quốc hội theo Hiến pháp 2013 và một số kiến nghị bảo đảm thực hiện / Functions of the National Assembly according to the 2013 Constitution and some recommendations for implementation” (2017) State Organization Research Journal, online: <https://tcnn.vn/news/detail/ 37025Chuc_nang_cua_Quoc_hoi_theo_Hien_phap_2013_va_mot_so_kien_n ghi_bao_dam_thuc_hienall.html>.

Minh Duyen, "Việt Nam đạt nhiều thành tựu về quyền con người / Vietnam’s achievements on human rights"”, (16 July 2020), online: Trang thông tin điện tử - Hội đồng lý luận TW <http://hdll.vn/vi/nghien-cuu---trao-doi/vie\%CC\%A3tnam-da\%CC\%A3t-nhie\%CC\%80u-tha\%CC\%80nh-tu\%CC\%A3u-ve\%CC\%80quye\%CC\%80n-con-nguo\%CC\%80i.html>.

Ministry of Foreign Affairs, National report - Universal periodic review on human rights assurance in Vietnam, 2nd period, by Ministry of Foreign Affairs (2020).

—, National report - Universal periodic review on human rights assurance in Vietnam, 3rd period, by Ministry of Foreign Affairs (2020).

Ministry of Justice, "Ưu tiên ban hành các luật về quyền con người / Priorities on issuing human rights laws”, online: <https://moj.gov.vn/tctccl/tintuc/Pages/tintuc-hoat-dong.aspx?ItemID=260>.

Ngo Thi Hai Anh, "Đẩy mạnh cải cách tư pháp nhằm xây dựng và hoàn thiện nhà nước pháp quyền xã hội chủ nghĩa / Promote judicial reforms to build and perfect the socialist rule of law state" (2019) State Management Journal, online: <https://www.quanlynhanuoc.vn/2019/12/12/day-manh-cai-cach-tu-phap-nhamxay-dung-va-hoan-thien-nha-nuoc-phap-quyen-xa-hoi-chu-nghia-3/> .

Nguyen Sinh Hung, "Vietnamese National Assembly - 70 years of constitutional history” (2016) The Communist Review No 879, online: $<$ http://vietnamlawmagazine.vn/vietnamese-national-assembly-70-years-ofconstitutional-history-5319.html>.

Nguyen Thi Hong Yen \& La Minh Trang, The National Assembly and the postlegislative scrutiny issue under the Constitution of Vietnam (2019).

Office of the High Commissioner, United Nations Human Rights, "OHCHR | HRC Membership of the Human Rights Council, 1 January - 31 December 2020”, (10 September 2020), online: Office of the High Commissioner, United Nations Human Rights <https://www.ohchr.org/EN/HRBodies/HRC/Pages/Current Members.aspx>. 
Phan Dien, "Resolution on overseas Vietnamese, date issued Mar. 26, 2004, No. 36NQ/TW.”, online: <http:/quehuongonline.vn/van-ban-phap-luat/resolution-no36-nqtw--march-26-2004-by-the-politbureau-on-the-overseas-vietnamese-affairs6866.htm>.

Phan, Huong \& Huong, "The Role of Vietnamese Government in Legislation - in Comparison with Japan” (2014) 11 Center for Asian Legal Exchange, Nagoya University (CALE Discussion Paper) 15.

Socialist Republic of Vietnam, Vietnam's Voluntary National Review on the Implementation of the Sustainable Development Goals (2018).

The Law on Environmental Protection 2014.

Tran Ngoc Duong, Quy trình hoạt động giám sát của Quốc hội/Monitoring process of the National Assembly (2020).

Tran Thi Hoe, "Nhà nước Việt Nam đối với việc bảo đảm quyền con người trong điều kiện hội nhập quốc tế hiện nay / Vietnam’s government and the assurance of human rights in the current context of international integration" (2016) 85:4 Human research Journal, online: <https://vass.gov.vn/nghien-cuu-khoa-hoc-xahoi-va-nhan-van/nha-nuoc-viet-nam-doi-voi-viec-bao-dam-quyen-con-nguoitrong-dieu-kien-hoi-nhap-quoc-te-hien-nay-74>.

TTX, "Việt Nam tiếp tục hoàn thiện pháp luật bảo đảm quyền con người/ Vietnam continues to improve laws to ensure human rights", (2019), online: $<$ http://tuyengiao.vn/dan-so-va-phat-trien/viet-nam-tiep-tuc-hoan-thien-phapluat-bao-dam-quyen-con-nguoi-125825>.

Tuyet Nhung, "Điểm mặt” 10 công ty gây ô nhiễm nghiêm trọng nhất ở Việt Nam / 'Pointing out' 10 companies that caused serious pollution in Vietnam”, (3 August 2016), online: <https://www.thiennhien.net/2016/08/03/diem-mat-10-cong-tygay-o-nhiem-nghiem-trong-nhat-o-viet-nam/> .

United Nations in Vietnam, "Common Country Assessment for Vietnam 2015", (2016), online: <https://vietnam.un.org/sites/default/files/2019-06/CCA_ final_eng-SD-NTNN-Aug\%2016.pdf $>$.

Uong Chu Luu, những nội dung cơ bản của Hiến pháp Nước Cộng hòa xã hội chủ nghĩa Việt Nam / Main Contents of the Socialist Republic of Vietnam's Constitution (Quangtri Department of Natural Resources and Environment, 2014).

Vietnam Government Portal, "Introduction about Political system of Vietnam", (2019), online: <http://chinhphu.vn/portal/page/portal/English/TheSocialistRepublicOfVietna $\mathrm{m} /$ AboutVietnam/AboutVietnamDetail? categoryId=10000103\&articleId=1000 $1578>$.

Vietnam National Assembly, "The 2013 Constitution of the Socialist Republic of Vietnam”, (2013), online: <http://vietnamlawmagazine.vn/the-2013-constitutionof-the-socialist-republic-of-vietnam-4847.html> . 
Vu, Giao Cong \& Kien Tran, "Constitutional Debate and Development on Human Rights in Vietnam” (2016) 11:2 Asian Journal of Comparative Law 235-262.

Vo Trung Tin \& Nguyen Thi Hong Phuong, "Tiếp cận thông tin môi trường nhằm đảm bảo quyền con người được sống trong một môi trường không bị ô nhiễm trong Luật BVMT 2005/ Access to information about environment to ensure the human right to live in an environment without pollution in the Law on Environmental protection" (2012) State and Laws Journal.

World Bank \& Ministry of Planning and Investment of Vietnam, Vietnam 2035: Toward Prosperity, Creativity, Equity, and Democracy (2016).

WTO Center VCCI, "Yếu tố lao động trong các FTA thế hệ mới / Labor factor in new generation FTAs”, online: <https:/trungtamwto.vn/hiep-dinh-khac/13303yeu-to-lao-dong-trong-cac-fta-the-he-moi>.

Yen Thi, Báo cáo Hiện trạng Môi trường quốc gia 2019: Nhận diện nguồn gây ô nhiễm / Report on national environmental situation 2019: Identify the polluting sources, by Yen Thi (Báo Tài nguyên \& Môi trường, 2020).

Dr. Nguyen Thi Hong Yen is an expert on human rights law in Vietnam with nearly 15 years researching and teaching in the field. She is currently Head of Public International Law Division of Hanoi Law University (HLU) of Vietnam and the Founding Member of Asian Association of Law Professors (AALP) and member of Vietnam Association of International Law (VSIL). She has carried out some research projects and published a lot of books and articles in prestigious law journals in Vietnam and international workshop/conferences regarding to the above concerns. From 2012-2015 she was known as an independent expert who joined to build up the National Action Plan on the Implementation of the recommendations accepted by Vietnam during the 2nd cycle of UPR. She also did the middle-term research on human rights at The Raoul Wallenberg Institute of Human Rights and Humanitarian Law (Lund University, Sweden) and became fellows at Norwegians Centre for human rights of Oslo University and The Hague Academy of International Law (The Netherlands). 